

\title{
MARKETING SYSTEM OF “GULA PASIR" SNAKE FRUIT IN BEBANDEM DISTRICT, KARANGASEM REGENCY
}

\author{
Dwi Dili Aprianna Putri*, Ketut Budi Susrusa, and Gede Mekse Korri Arisenna \\ Agribusiness, Faculty of Agriculture, Udayana University, Bali, Indonesia \\ Correspondence email: annaputri168@gmail.com
}

Submitted 25 July 2020; Accepted 14 Oct 2020

\begin{abstract}
ABSTRAK
Kecamatan Bebandem sebagai salah satu daerah penghasil salak gula pasir terbesar di Bali. Aspek pemasaran salak gula pasir merupakan hal penting dalam mendukung peningkatan pendapatan petani salak. Banyaknya lembaga tataniaga yang terlibat dalam pemasaran salak gula pasir mempengaruhi panjang pendeknya rantai tataniaga dan besarnya biaya tataniaga. Penelitian ini dilaksanakan untuk mengetahui saluran tataniaga salak gula pasir, serta mengetahui efisiensi pada sistem tataniaga salak gula pasir. Data dianalisis secara deskriptif terhadap analisis konsentrasi rasio, analisis perilaku pasar, analisis margin tataniaga, analisis farmer's share. Responden penelitian ini berjumlah 53 orang yang terdiri dari 32 orang petani salak gula pasir dan 21 orang pedagang. Lembaga tataniaga yang terlibat adalah pedagang pengumpul tingkat desa, pengumpul antar kabupaten/kota/pulau dan pedagang pengecer. Seluruh responden ditentukan dengan menggunakan metode snowball sampling. Hasil dari penelitian terdapat empat saluran tataniaga. Struktur pasar pada tingkat petani mengarah pada struktur pasar oligopsoni konsentrasi sedang. Perilaku pasar yang terjadi pada sistem tataniaga salak gula pasir sudah baik mengacu pada sistem pembayaran, kerja sama antar petani dan lembaga tataniaga. Saluran tataniaga IV merupakan saluran terpendek dan paling efisien dengan farmer's share sebesar $67 \%$ dan margin tataniaga sebesar Rp 500.000/qkudengan volume pendistribusian salak gula pasir sebesar $26,19 \%$.
\end{abstract}

Kata Kunci: efisiensi tataniaga, salak gula pasir, saluran tataniaga, struktur pasar, perilaku pasar

\begin{abstract}
Bebandem Sub-district is one of the most significant Gula Pasir snake fruit-producing areas in Bali. The Marketing aspect is essential to support the increasing of gula pasir snake fruit farmer's income. Many trading institutions that are involved in the marketing of gula pasir snake fruit will affect the length of the trading chain and the amount of trading cost. This research was conducted to determine the gula pasir snake fruit trading channel, as well as to determine the efficiency of the gula pasir snake fruit trading system. Data were analyzed descriptively towards concentration ratio analysis, market conduct analysis, marketing margin analysis, farmer's share analysis. Respondents of this study were 53 people consisting of 32 gula pasir snake fruit farmers and 21 traders. The trading institutions involved are village-level collectors, inter-regency/city/island collectors and retail traders. All respondents that selected using the snowball sampling technique. There were 4 gula pasir snake fruit market channelling models. The market structure at the farm level leads to a medium concentration oligopsony. Market conduct that occurs in the gula pasir snake fruit trading system is already good, referring to the payment system, cooperation between farmers and trading institutions. The IV trading channel is the shortest and most efficient channel with a farmer's share of $67 \%$ and a marketing margin of IDR 500,000/q with a distribution volume of gula pasir snake fruit of $26.19 \%$
\end{abstract}

Keywords: efficiency marketing, gula pasir snake fruit, market structure, market conduct, marketing system 


\section{INTRODUCTION}

Bali is one of the provinces that produces snake fruit in Indonesia. According to the Statistics Indonesia (2019), it is stated that the largest producer of snake fruit fruit in Bali is Karangasem Regency. The highest production of snake fruit from 2014 to 2018 was in Karangasem Regency. The production of snake fruit in 2014 reached 66,389 tons, but it eventually experienced a significant decline every year to reach 18,622 tons in 2018. Nevertheless, Karangasem Regency is still the most snake fruit-producing regency in Bali. This is one of the opportunities to develop snake fruit commodity as one of the leading commodities in Karangasem Regency.

Bebandem District is one of the districts that accounts for more than $50 \%$ of snake fruit production in Karangasem Regency, also contributes more than $40 \%$ of snake fruit production in Bali Province each year. Since most of the snake fruit-producing villages are in Bebandem District, it makes snake fruit a source of income for the Bebandem community (Cahyani et al., 2013).

Rai et al. (2010) stated that the difference in the price of gula pasir snake fruit during the main harvest season and after the harvest season reached IDR 23,000 - IDR 26,000 , so that it leads to research on the marketing system of gula pasir snake fruit in Bebandem District, Karangasem Regency. The price of gula pasir snake fruit at harvest can reach IDR 7,000 - IDR 9,000. When not harvesting, the price reaches IDR 30,000 IDR 35,000 per kilogram. The price fluctuation is a common phenomenon that occurs due to instability on the supply side. Snake fruit plants are mostly harvested from January to February. These months are the main harvest season for the snake fruit plant, so the price earned by farmers is still relatively cheap. Meanwhile, outside the harvest season, the snake fruit can be sold at a higher price than the price during the harvest season. Seeing the characteristics of snake fruit that is perishable, the farmers have a little difficulty in selling it during the harvest season because many farmers sell their snake fruit, so the farmers have to let their snake fruit be sold at a low price so that it can be sold quickly. It is the nature of agricultural products that cannot respond to additional demand when prices are high and cannot reduce production when prices are low.

Suharyanto et al. (2015) explained that the quality and price of agricultural products is a marketing problem which has a direct impact on the parties involved in the distribution of agricultural products. The location of agricultural land is far from the center of the economy which results in the formation of a long marketing chain because it is distributed through many intermediary merchants. Until now, gula pasir snake fruit has only been sold without being processed into other products, so it takes a fast time to reach to consumers in fresh conditions. The amount of marketing agencies involved in the marketing of gula pasir snake fruit affects the length of the marketing channels and the speed at which the products reach consumers. The length of the marketing channel also affects the amount of marketing costs which will affect the difference in product prices from producers and consumers. The relationship between the price earned by farmers and the price paid by consumers depends on the market structure in the marketing system.

The conditions for the development of snake fruit prices are more dominantly controlled by collectors and retailers. These merchants have great power in pricing and earning a profit. If farmers sell their goods to collectors, the price earned is usually lower than the previous merchants. This is because the price information system often does not reach farmers at the right time (Dyanasari et al., 2010). Therefore, the most efficient and profitable alternative marketing channel is required for each marketing agencies involved in the marketing of gula pasir snake fruit. To measure the quality of the marketing system of a gula pasir snake fruit, a market analysis can be carried out in terms of market 
structure, market behavior, and market performance. The objective of this study was to determine the marketing channel of gula pasir snake fruit in Bebandem District, Karangasem Regency, to analyze the market structure at the farmer level, and market conduct, and to analyze the operational efficiency of the marketing system in each channel.

\section{RESEARCH METHODS}

\section{Research Methods and Sampling}

The research location was selected purposively, which was the largest snake fruit producer, the Bebandem District, Karangasem Regency. In practice, it involved three villages that produced gula pasir snake fruit in Bebandem District, Karangasem Regency, including Sibetan Village, Jungutan Village, and Bebandem Village. The three villages used in this study were selected as they had a village market which made it easier to find the marketing channels of gula pasir snake fruit. The respondents in this study were respondent farmers and marketing agencies. The determination of the research sample used the snowball sampling method from collector respondents and farmer respondents. The sampling began from village-level collectors and then followed the marketing arrangement which obtained farmer respondents and marketing agencies. The farmer respondents were 32 people and collector respondents were 22 people consisting of collectors at the village/intercity/regency/island levels.

The type of data in this study was qualitative data and quantitative data. The data sources in this study were primary data obtained directly by interviewing farmers and collectors of gula pasir snake fruit, such as regarding the cost, price, sales volume, and purchase of gula pasir snake fruit, while the secondary data in this study were the Central Agency on Statistics, the Agriculture of Food Crops and Horticulture Office, Karangasem Regency, and literature and other sources related to the research title. The methods of data collection were by conducting interviews, surveys, and documentation during research. The variables in this study were the marketing channel, the functions of the marketing channel, the market structure, market conduct, and the efficiency of the marketing system.

\section{Data Analysis Methods}

Analysis using qualitative methods was used to analyze channels and marketing agencies, analysis of marketing functions, analysis of market structures, and analysis of market conduct. Meanwhile, quantitative analysis was carried out to analyze the concentration ratio. The market conduct was analyzed qualitatively by looking at the payment system and the division of regions in each marketing agency. The efficiency of marketing will be analyzed by calculating the marketing margin and farmer's share, and economic efficiency.

\section{Marketing Channel Analysis}

The marketing channel was analyzed by identifying market players involved in the delivery of the gula pasir snake fruit commodity from farmers to the final consumers. Moreover, an analysis of marketing system functions was conducted by observing the functions or activities carried out by each farmer, marketing agency, and consumer in distributing gula pasir snake fruit from farmers to consumers. The marketing system functions were measured by looking at the various marketing channels involved in the marketing flow of gula pasir snake fruit. In the analysis, the functions of the marketing system were adjusted to the number of marketing channel agencies in the research area. There were three functions of the marketing system, including the exchange function, the physical function, the facility function.

\section{Market Structure Analysis}

Analysis of the market structure of gula pasir snake fruit at the farmer level can be carried out by quantitative analysis, which 
is by analyzing the market concentration. The analysis of the market structure at the farmer level was carried out by looking at the transactions of marketing agencies that made direct transactions to gula pasir snake fruit farmers, which were systematically formulated as follows (Hay and Moris, 1992 in Rahayu, 2013):

$$
\mathrm{KR}_{4}=\frac{S 1+S 2+S 3+S 4}{S n} \times 100 \%
$$

\section{Notes:}

$\mathrm{S} 1=$ gula pasir snake fruit merchant 1 (q/season)

$\mathrm{S} 2$ = gula pasir snake fruit merchant 1 (q/season)

$\mathrm{S} 3$ = gula pasir snake fruit merchant 1 (q/season)

S4 = gula pasir snake fruit merchant 1 (q/season)

$\mathrm{Sn}=$ total of all sales of the level one agency of gula pasir snake fruit ( $\mathrm{q} / \mathrm{season})$
This concentration ratio is only applied for the first marketing agency, so that it can be seen the control of the gula pasir snake fruit marketing at the farmer level with the following conditions (Hay and Morris, 1992 in Rahayu, 2013)

1 If one merchant (Kr1) has a value of $\mathrm{Kr}$ of $95 \%$, the market is a monopsony competition market.

2 If there are four merchants (Kr4) whose $\mathrm{Cr}$ value is less than $80 \%$, the market leads to moderate concentration oligopsony.

3 If there are four merchants $(\mathrm{Kr} 4)$ whose Cr value is more than or equal to $80 \%$, the market leads to high concentration oligopsony.

\section{Market Conduct Analysis}

Analysis of the gula pasir snake fruit market conduct was carried out by observing the strategies implemented by each merchant in overcoming the problems encountered. More specifically, the analysis of market

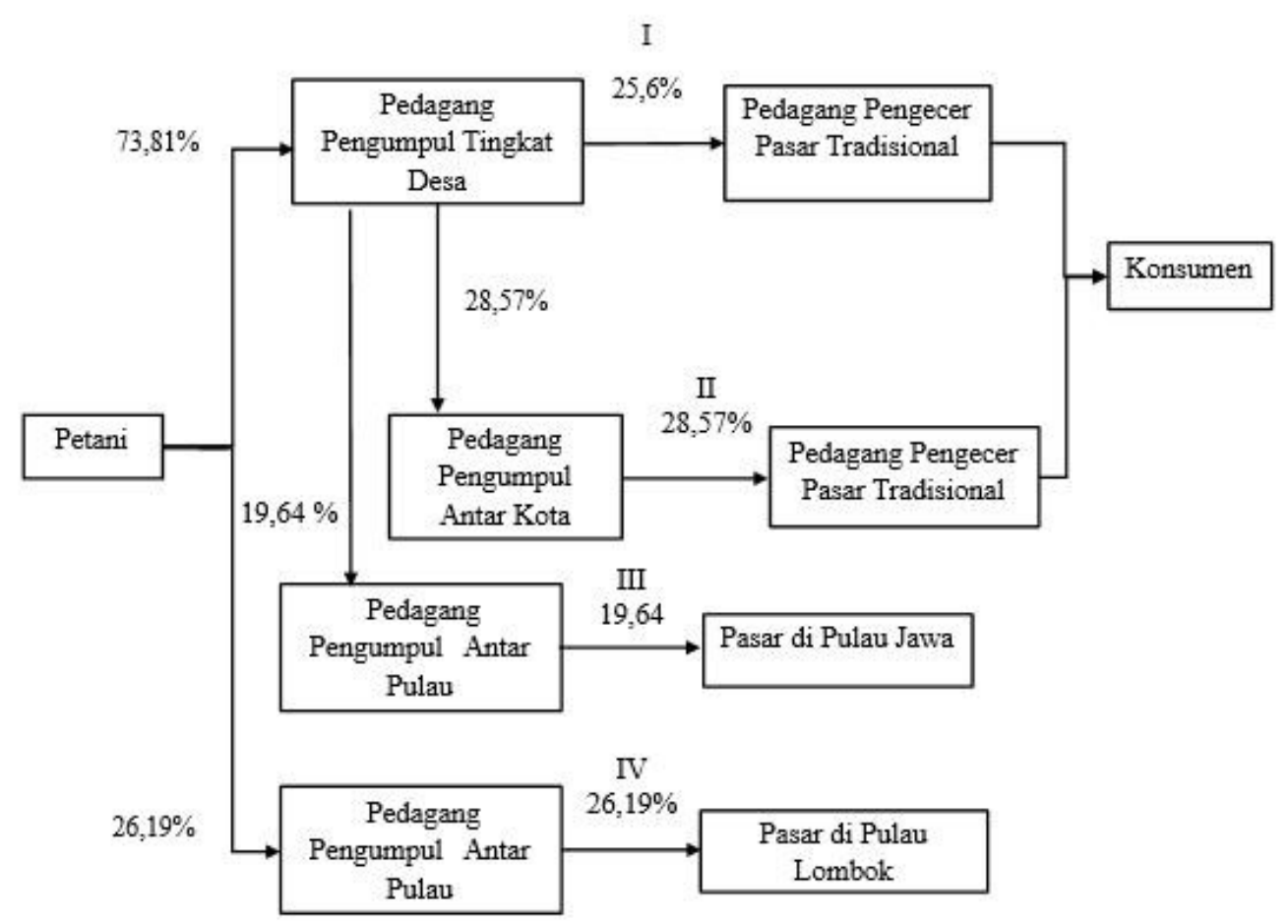

Figure 1. The Gula Pasir Snake Fruit Trading Management Channel in Bebandem District, Karangasem Regency Source: Primary Data (Processed) 
Table 1. Functions Performed by the Gula Pasir Snake Fruit Trade Organization in Bebandem District, Karangasem Regency

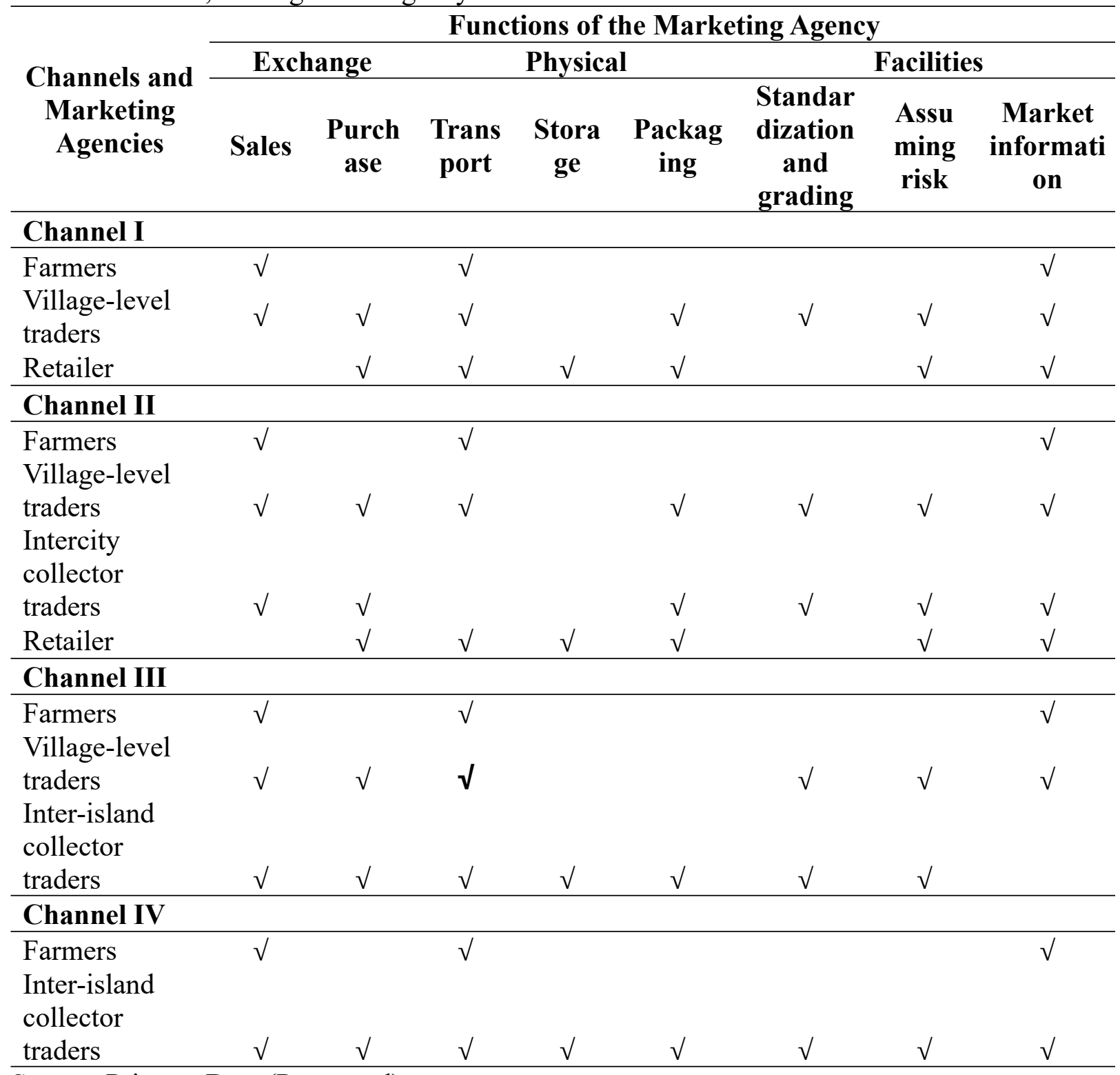

Source: Primary Data (Processed)

conduct was carried out by analyzing the system of cooperation between marketing agencies by considering the division of areas for buying and selling gula pasir snake fruit and the payment system which was carried out by a qualitative analysis.

Efficiency of the Marketing System Analysis

The efficiency of the marketing system in the gula pasir snake fruit marketing system can be calculated by using the operational (technical) efficiency indicator value using marketing margin analysis and farmer's share (Diwandani and Harianto, 2012).

a Marketing Margin is the value of the marketing margin affected by the marketing channel of the commodity. The value of marketing margin can be calculated using the following formula:

Notes:

$$
\mathrm{MP}=\operatorname{Pr}-\mathrm{Pf}
$$

$\mathrm{MP}=$ Marketing Margin

$\operatorname{Pr}=$ Price at the final level of marketing goals (IDR/q)

Pf $=$ Price at the producer level (IDR/q) 
Table 2. Purchasing Volume and Concentration Ratio of Gula Pasir Snake Fruit by Marketing Institutions Directly to Farmers

\begin{tabular}{clcc}
\hline No & Name & $\begin{array}{c}\text { Purchase Amount } \\
\text { (quintal) }\end{array}$ & $\begin{array}{c}\text { KRx } \\
(\%)\end{array}$ \\
\hline 1 & Inter-island traders & 44 & 26 \\
2 & Village traders 1 & 20 & 38 \\
3 & Village traders 2 & 18 & 49 \\
4 & Village traders 3 & 16 & 58 \\
5 & Village traders 4 & 13 & 66 \\
6 & Village traders 5 & 12 & 73 \\
7 & Village traders 6 & 11 & 80 \\
8 & Village traders 7 & 10 & 86 \\
9 & Village traders 8 & 9 & 91 \\
10 & Village traders 9 & 9 & 96 \\
11 & Village traders 10 & 6 & 100 \\
\hline
\end{tabular}

Source: Primary Data (Processed)

b Farmer's share analysis is the value of share received by farmers by comparing the price paid by consumers to the price of products received by farmers (Sudiyono, 2002). The value of the farmer's share can be calculated based on the following formula:

$$
\text { Farmer's Share }=\frac{P r}{P f} \times 100 \%
$$

Notes:

$\mathrm{Pf}=$ Price at the farmer level

$\operatorname{Pr}=$ Price paid by the final customer

c To determine the economic efficiency, it can be measured by the percentage value of the marketing margin and the share received by the producer. The criteria used to determine that marketing is considered economically efficient is if each marketing channel has a low marketing margin and a high percentage value of the share received by producers (Darmawati, 2005).

\section{RESULTS AND DISCUSSION}

\section{Marketing Channel Agencies}

The marketing agencies involved in this study were collectors at the village/intercity/regency levels, inter-island collectors, and retailers on Bali Island. There were six types of gula pasir snake fruit marketing channels in Bebandem District, Karangasem Regency, including 1) Farmers - VillageLevel Collectors - Traditional Market Retailers - Consumers; 2) Farmers - VillageLevel Collectors - Inter-City Collectors Traditional Market Retailers - Consumers; 3) Farmers - Village-Level Collectors - InterIsland Collectors - Java Island Market; 4) Farmers - Inter-Island Collectors - Lombok Island Market. Sales of gula pasir snake fruit through village-level collectors were $73.81 \%$ and direct sales to inter-island collectors were $26.19 \%$.

\section{Marketing Agency Functions}

The marketing agency functions that were carried out included the physical function, exchange function, and facility function. The marketing agencies carried out different functions based on the needs of each agency to fulfill the needs of the customers. The exchange function carried out included the selling and buying of gula pasir snake fruit. The physical function carried out included transportation, product storage, and packaging. The facility function carried out included standardization and grading, risk assumption, and market information. The following is a table of the functions carried out by each marketing system. 
Table 3. Marketing Margin of Gula Pasir Snake Fruit in Bebandem District, Karangasem Regency

\begin{tabular}{cccc}
\hline Channel & $\begin{array}{c}\text { Price at Farmer Level } \\
(\text { IDR/q) }\end{array}$ & $\begin{array}{c}\text { Price at Retail Level } \\
\text { (IDR/q) }\end{array}$ & $\begin{array}{c}\text { Trading Margin } \\
\text { (IDR/q) }\end{array}$ \\
\hline I & 900.000 & 1.620 .000 & 720.000 \\
II & 900.000 & 1.800 .000 & 900.000 \\
III & 900.000 & 1.500 .000 & 600.000 \\
IV & 1.000 .000 & 1.500 .000 & 500.000 \\
\hline
\end{tabular}

Source: Primary Data (Processed)

\section{Market Structure at the Farmer Level}

Analysis of market structure at the farmer level of gula pasir snake fruit in Bebandem District, Karangasem Regency was carried out by using a concentration ratio. It considered the volume purchased directly by marketing agencies to farmers. The measurement of the concentration ratio was carried out by combining the four highestselling volumes of first-level marketing agencies (village-level collectors and interisland collectors) who made direct purchases to farmers in the gula pasir snake fruit marketing system in Bebandem District, Karangasem Regency. Village-level collectors and inter-village collectors are collectors who were involved in buying gula pasir snake fruit during the study. The data processed were data collected during the main harvest, which was from January to March 2020. The market structure of gula pasir snake fruit at the farmer level in Bebandem District, Karangasem Regency results in a moderate concentration oligopsony market. It can be seen in Table 2 that the concentration of the selling volume of the four marketing agencies is $58 \%$.

According to some researchers, market structures that have moderate concentration tend to have a sufficient level of price competition among marketing agencies and the goods distribution is not only concentrated in the research area. Based on the results of field research on the marketing system of gula pasir snake fruit, it shows that there is sufficient price competition. Besides, the marketing channel can reach the scope beyond the research area.

\section{Market Conduct \\ Inter-Agency Cooperation}

In the gula pasir snake fruit marketing system, there is no division of areas for farmers or marketing agencies in the selling and buying of gula pasir snake fruit. Farmers are free to sell their snake fruit anywhere and collectors are also free to buy and sell their snake fruit anywhere, all transaction is based on the conditions that occur at that time. The absence of cooperation among agencies reflects the absence of an alliance among merchants to decrease the price of gula pasir snake fruit and force farmers to sell their snake fruit at a very cheap price. The farmers sell their snake fruit to regular customers who bought their snake fruit previously. Some farmers sell their snake fruit to regular collectors because they come directly to the farmer's place to buy their snake fruit. This is due to the farmer's house that is quite far from the market and limited access to the market.

\section{Payment System}

The payment system applied in the gula pasir snake fruit marketing system is different at each level of the agency. For farmers, the payment system is provided in cash which is directly paid during the transaction process. Village-level collectors who sell directly to collectors at the intercity/regency/island levels and retailers earn cash directly from the retailers.

\section{Efficiency of the Marketing System}

The analysis of operational (technical) efficiency is an analysis used to calculate the efficiency of the gula pasir snake fruit 
Table 4. Gula Pasir Snake Fruit Farmer's Market Share in Bebandem District, Karangasem Regency

\begin{tabular}{ccc}
\hline No & Marketing Channel & Farmer's Share (\%) \\
\hline 1 & I & 56 \\
2 & II & 50 \\
3 & III & 60 \\
4 & IV & 67 \\
\hline
\end{tabular}

Source: Primary Data (Processed)

marketing system in Bebandem District, Karangasem Regency, by using a margin analysis of marketing system, farmer's share, and economic efficiency of the gula pasir snake fruit marketing system by comparing the marketing margin and farmer's share.

\section{Marketing Margin}

The marketing margin analysis is used to calculate the difference between the price at the farmer level and the price paid by the consumer and the final marketing agency. These costs included transportation costs, packaging costs, rental costs, and labor costs (for harvesting, sorting, and grading). The costs were calculated based on the marketing functions carried out by each marketing agency.

Based on Table 3, the pattern of the marketing channel I shows that the farmers sold gula pasir snake fruit to village-level collectors and then it was sold to retailers. The price of gula pasir snake fruit at the farmer level was IDR 900,000/q which was purchased by village-level collectors. Then, the village collectors sold them to traditional market retailers The marketing margin on the channel I was IDR 720,000/q. In channel II, the pattern of marketing channel II involved village-level collectors, inter-city collectors, and retailers. The goal of this marketing was traditional markets in Denpasar City. The volume of gula pasir snake fruit originating from collectors through the marketing channel II was $28.57 \%$. Village-level collectors collected the harvest of gula pasir snake fruit, then brought them to the village market to be sold again to collectors at the inter-city/inter-island levels. Then, the intercity collectors brought the gula pasir snake fruit to traditional markets in Denpasar City and carried out transactions to retailers.

Channel III involved farmers, villagelevel collectors, and inter-island collectors. The goal of this marketing was the markets in Java Island. Village-level collectors collected the harvest of gula pasir snake fruit, then brought them to the village market to be sold again to collectors at the inter-city/inter-island levels. The volume of gula pasir snake fruit originating from village-level collectors through the marketing channel III was $19.64 \%$. Then, the inter-island collectors sent the gula pasir snake fruit to the markets in Java Island.

Channel IV was the shortest marketing channel among all the gula pasir snake fruit marketing channels in Bebandem District, Karangasem Regency. This channel only involved farmers and inter-island collectors. The inter-island collectors bought gula pasir snake fruit directly from farmers at

Table 5. Efficiency of Gula Pasir Snake Fruit Marketing Channel in Bebandem District, Karangasem Regency

\begin{tabular}{ccc}
\hline Marketing Channel & Marketing Margin (Rp/q) & Farmer's Share (\%) \\
\hline I & 720.000 & 56 \\
II & 900.000 & 50 \\
III & 600.000 & 60 \\
IV & 500.000 & 67 \\
\hline
\end{tabular}

Source: Primary Data (Processed) 
a price of IDR $1,000,000 / q$. The gula pasir snake fruit was then sold directly to merchants outside the island, which was Lombok Island at a selling price of IDR $1,500,000 / q$. The difference in price between the buying price and the selling price on the inter-island collectors was IDR 400,000/q. The marketing margin on channel IV was IDR 500,000/q.

\section{Farmer's Share}

The share received by farmers or farmer's share is the ratio percentage of the share of the price received by the farmer and the price paid by consumers or the final level marketing agency in the marketing channel. A high farmer's share is not absolutely used to show that marketing runs efficiently (Diwandani and Harianto, 2012).

Table 4 explains each farmer's share of the gula pasir snake fruit in Bebandem District, Karangasem Regency, on each different channel. The difference in farmer's share in each channel was due to the difference in the number of marketing agencies in distributing gula pasir snake fruit. The highest farmer's share was on channels III and IV with $60 \%$ and $67 \%$, respectively. The lowest farmer's share was on channel II, which was $50 \%$.

The length of the channel affects the value of the share received by farmers. The shorter the marketing channel, the higher the share received by farmers. On the other hand, if the marketing channel is longer, the share received by farmers will also lower. The costs and benefits obtained by each marketing agencies also affect the farmer's share. The higher the costs required by the marketing agencies, the lower the farmer's share. In the gula pasir snake fruit marketing channel in Bebandem District, Karangasem Regency, the marketing channel IV was the shortest marketing channel and the lowest marketing margin.

\section{Economic Efficiency}

Economic efficiency can be calculated by comparing the lowest marketing margin and the higher farmer's share. The value of the marketing margin can be affected by the large number of marketing functions carried out by the marketing agencies which cause the high costs incurred by each marketing agency.

Based on Table 5, the lowest margin and highest farmer's share is in channel IV. The margin was IDR 500,000/q with a farmer's share of $67 \%$. Channel IV was the shortest channel, which was from farmers who directly sold snake fruit to inter-island collectors. Channel IV was the most efficient channel among other gula pasir snake fruit marketing channels.

The channel with the highest margin was channel II with a value of IDR 900,000/q. The value of the margin of channel II was due to the difference in prices at the farmer level and consumer level or the final marketing agency which the gap was too high. Marketing channel II had a farmer's share of $50 \%$. This channel also involved many marketing agencies and was the longest channel of the other channels. The length of the marketing channel on channel II resulted in the higher costs required in distributing gula pasir snake fruit to reach consumers. A large amount of margin and the low farmer's share resulted in this channel being less effective in distributing gula pasir snake fruit in Bebandem District, Karangasem Regency.

\section{CONCLUSIONS}

There were four types of gula pasir snake fruit marketing channels in Bebandem District, Karangasem Regency, including 1) Farmers - Village-Level Collectors Traditional Market Retailers - Consumers; 2) Farmers - Village-Level Collectors - InterCity Collectors - Traditional Market Retailers - Consumers; 3) Farmers - Village-Level Collectors - Inter-Island Collectors - Java Island Market; 4) Farmers - Inter-Island Collectors - Lombok Island Market. Each marketing system carried out the main function of the marketing system, consisting of the exchange function, the physical 
function, and the facility function. The marketing structure of gula pasir snake fruit in Bebandem District, Karangasem Regency, at the farmer level led to a moderate concentration of oligopsony market structure. The market conduct in the gula pasir snake fruit marketing system was good with a cooperation system among agencies and a payment system at the farmer level that earned cash quickly. The efficiency of the marketing system seen from the margin of each channel resulted that the most efficient channel was channel IV with a farmer's share of $67 \%$ and a margin of IDR 500,000/q. Besides having the shortest marketing channel with a sales volume of $26.19 \%$ of gula pasir snake fruit, channel IV was the most efficient channel. The farmers are suggested to sell their snake fruit directly to inter-island collectors because they had the smallest margin and the highest farmer's share. The farmers are also expected to be able to increase the productivity and quality of gula pasir snake fruit so that they can sell their snake fruit at a higher price. Snake fruit plants that are not productive should be replaced immediately to increase the productivity of gula pasir snake fruit.

\section{REFERENCES}

Statistics Indonesia. 2019. Bali dalam angka 2019. Available in http://BPS.go.id. Accessed 5 September 2019

Statistics Indonesia. 2019. Kabupaten Karangasem dalam angka 2019. Available in http://BPS.go.id. Accessed 5 September 2019

Statistics Indonesia. 2019. Kecamatan Bebandem dalam angka 2019. Available in http://BPS.go.id. Accessed 18 Juli 2020

Cahyani, N. K. W., M. Suryadi, and I. W. Treman. 2013. Persebaran kebun salak gula pasir (Zalacca Var. Amboinensis) di Kecamatan Bebandem Kabupaten Karangasem (Suatu pedekatan keruangan). Jurnal Pendidikan Geografi Undiksha

$$
1(2) \text { : }
$$$$
\text { 1-10. }
$$

\section{Http://dx.doi.org/10.23887/jijgg.v1i3.20}

$\underline{693}$

Darmawati. 2005. Analisis pemasaran mendong di Kabupaten Sleman. Skripsi. Universitas Sebelas Maret. Surakarta.

Diwandani, G. A. and Harianto. 2012. Analisis sistem tataniaga kentang di Kecamatan Kayu Karo Kabuoaten Kerinci Provinsi Jambi. Skripsi. Institut Pertanian Bogor. Bogor.

Dyanasari, Wahyunindyawati, Asnah, and F. Kasijadi. 2010. Pendekatan SCP pada pengukuran efisiensi pemasaran bawang merah di Kabupaten Probolinggo. Buana Sains 10(1): 57-66. https://jurnal.unitri.ac.id/index.php/buan asains/article/view/249

Rahayu, E. S. 2013. Analisis struktur pasar (market structure) jagung di Kabupaten Grobogan. Jurnal of Rural and Development 4(1): 1-17. https://jurnal.uns.ac.id/rural-anddevelopment/article/view/23372

Rai, I. N., C. G. A. Semarajaya, and I. W. Wiraatmaja. 2010. Studi fenofisiologi pembungaan salak gula pasir sebagai upaya mengatasi kegagalan fruit-set. Jurnal Hortikultura 20(3): 216-222. Http://ejurnal.litbang.pertanian.go.id

Sudiyono. 2002. Pemasaran pertanian. Malang: UMM Press.

Suharyanto, I. A. P. Parwati, and J. Rinaldi. 2015. Analisis pemasaran dan tataniaga anggur di Bali. SOCA: Jurnal Sosial Ekonomi Pertanian 8(1): 1-16. https://ojs.unud.ac.id/index.php/soca/artic le/view/4181

Sukmawati, E. A. 2015. Analisis tataniaga buah manggis di Desa Cikalong, Kecamatan Sodonghilir, Kabupaten Tasikmalaya, Jawa Barat. Skripsi. Institut Pertanian Bogor. Bogor. 